\title{
Potential Energy Production from Biogas Economically and Environmental Profitable. Case Study: Establishing a Batch Digester in "Fogi" Farm
}

\author{
Holta Prifti, Tania Floqi, and Mirel Mico
}

\begin{abstract}
Recently the use of biomass for biogas production is very limited in Albania. According to data acquistion from the study, the highest share in the entire structure of urban solid waste is that of organic waste $41-61.2 \%$.

A large part of these waste are bio digestible and can used for production or utilized as potential substrate in anaerobic digestion to produce biogas, a renewable source of energy and environment friendly too.

Live stocks waste and especially cow manure farms are concerned in this study because there are a high number 11813 of them are spread all over Albania. In addition, the amount of cow manure exceeds 37,693.92 ton/year.

In this case study is presented a cow farm located near Tirana, capital city of Albania with 200 cow heads which in the future will become 700 cow heads. The total amount of cow manure produced in this farm is $\mathbf{1 8 2 5}$ ton/year, a considerable quantity of manure available for biogas production.

This paper presents the type of digester, calculation of the biogas production yield, the optained energy, the pay back period of the initial investment and the net present value of this farm batcher digestor.
\end{abstract}

Index Terms - batch digester, biogas production, cow farms, cow manure, cost investment, energy.

\section{INTRODUCTION}

After 1990s in Albania, the data indicate a significant increase in urban waste generation. In the total percentage of solid urban waste, organic waste component represents the highest percentage (41-66\%) at the waste composition. Many livestock farms were developed. Recently the number of them is increase up to 23654 and approximately $50 \%$ of them are cow farms, as shown in the Table I. In 2020 the waste forms the livestock sector is estimated 383,234.4 ton. [1].

As is shown in the Table I the quantity of cow manure in 2020 in Albania is approximately 37,693.92 ton/year.

The reasons that is chosen cow manure farm are: the substrate quality for biogas production, the high quantity of available manure, the methane production yield up to $63 \%$. [2], [10], [9].

The results on biogas production in laboratory scale from cow manure $\left(25 \mathrm{Nm}^{3} /\right.$ ton $)$ are very optimistic to implement in the concrete cow farm with 200 cow's heads.

Submitted on June 17, 2021

Published on July 27, 2021.

Holta Prifti, National Agency of Protected Areas, Ministry of Tourism and Environment, Albania.

(e-mail: holtaprifti@yahoo.com)

Tania Floqi, Department of Engineering and Architecture, Faculty of Engineering, Informatics and Architecture, UE, Tirana, Albania.

(e-mail: floqitania@yahoo.com)

\begin{tabular}{cccc}
\multicolumn{4}{c}{ TABLE I: THE QUANTITY OF COW MANURE IN ALBANIA } \\
\hline Region & $\begin{array}{c}\text { Number } \\
\text { of cow } \\
\text { farms }\end{array}$ & $\begin{array}{c}\text { Cow heads } \\
(+5)\end{array}$ & $\begin{array}{c}\text { Manure } \\
\text { quantity }(\mathrm{kg})\end{array}$ \\
\hline BERAT & 542 & 5266 & 1553470 \\
DIBER & 593 & 5004 & 1476180 \\
DURRES & 529 & 5574 & 1644330 \\
ELBASAN & 488 & 4073 & 1201535 \\
FIER & 1687 & 16795 & 4954525 \\
GJIROKASTER & 455 & 9737 & 2872415 \\
KORCE & 1365 & 15253 & 4499635 \\
KUKES & 1749 & 13481 & 3976895 \\
LEZHE & 868 & 8347 & 2462365 \\
SHKODER & 1407 & 12816 & 3780720 \\
TIRANE & 1203 & 10791 & 3183345 \\
VLORE & 927 & 20639 & 6088505 \\
Total & 11813 & 127776 & 37693920 \\
\hline
\end{tabular}

\section{Materials AND Methods}

As mentioned above, the study aimed to establish a biogas production plant with cow manure nearby the "Fogi" Farm, located in Kashar village, approximately $15 \mathrm{~km}$ far away from Tirana, with a maximal capacity of 700 cow heads.

- Total surface area of the farm is $12,500 \mathrm{~m}^{2}$.

- $\quad$ Building surface + stalls is $5500 \mathrm{~m}^{2}$ (Close system). Cow manure is collected within an open area in a natural dump.

- Actually, this farm has 200 cow heads.

- One head produces approximately 20 - $30 \mathrm{~kg}$ manure/day

- $\quad$ Average monthly consumption of electric energy is $3381 \mathrm{kWh} /$ year.

- The price of electricity is 14 ALL/ $\mathrm{kWh}$ without VAT. $(0.14 \$)$

- Heating-cooling system for the building is assumed from heat pumps.

Taking in consideration that one head produces $20-30 \mathrm{~kg}$ manure per day, 200 head of cows produce 5 tons of waste per day so 150 tons of waste in 30 days.

Cow litter density is $500 \mathrm{~kg} / \mathrm{m}^{3}$ :

- The plant will be a batch digester type similar like is shown in the Fig. 2.

- $\quad$ The digester volume $-300 \mathrm{~m}^{3}$.

- $\quad$ Retention time - 30 days.

Prof. Mirel Mico, lecture, Department of Environment, Faculty of Civil Engineering, Polytechnic University of Tirana, Albania.

(e-mail: mmico818@ hotmail.com) 
The samples of cow manure are analyzed in the biogas lab. The method applied for the cow manure samples is the same that mentioned [3]-[5] for biogas production in laboratory scale.

\section{RESULTS AND DISCUSSION}

The biogas produced in the laboratory scale from cow manure is approximately $25 \mathrm{Nm}^{3} /$ ton.

- Five-ton manure produce $125 \mathrm{Nm}^{3} /$ day biogas.

- The daily energy produced from the biogas quantity $125 \mathrm{Nm}^{3} /$ day $\times 9.67 \mathrm{kWh}=1208.75 \mathrm{kWh}$.

- The monthly energy produced is $36262.5 \mathrm{kWh}$, which can be used to generate heat and electricity.

- The monthly energy produced by generator is $36262.5 \mathrm{kWh} \times 0.37=13417 \mathrm{kWhel}($ see Table II, Fig. 1).

- Annually energy produced is $161 \mathrm{MWhel}$.

- Demand for electricity based on bills paid for one year is approximately $42664 \mathrm{kWhel} /$ year.

Annual gross profit taking in consideration the price of 14 ALL (0.14\$) per $1 \mathrm{kWh}$ is:

$\mathrm{Bt}=161000 \mathrm{MWhel} \times 14 \mathrm{ALL} / \mathrm{kWhel}=2254000 \mathrm{ALL}$ $(22540 \$)$

Annual net profit is the difference between energy produced from the generator and the demand for electricity $161000-42664=118336 \mathrm{kWhel}$, converted to monetary value 1656704 ALL (16 567 \$).

\begin{tabular}{|c|c|c|c|c|}
\hline Months & January & February & March & April \\
\hline Demand & 3849 & 3577 & 3672 & 3400 \\
\hline Incomes & 13417 & 13417 & 13417 & 13417 \\
\hline \multirow[t]{2}{*}{ Profits } & 9568 & 9840 & 9745 & 10017 \\
\hline & May & June & July & August \\
\hline Demand & 3256 & 3400 & 3900 & 3800 \\
\hline Incomes & 13417 & 13417 & 13417 & 13417 \\
\hline \multirow[t]{2}{*}{ Profits } & 10161 & 10017 & 9517 & 9617 \\
\hline & September & October & November & December \\
\hline Demand & 3361 & 3200 & 3462 & 3787 \\
\hline Incomes & 13417 & 13417 & 13417 & 13417 \\
\hline Profits & 10056 & 10217 & 9955 & 9630 \\
\hline
\end{tabular}

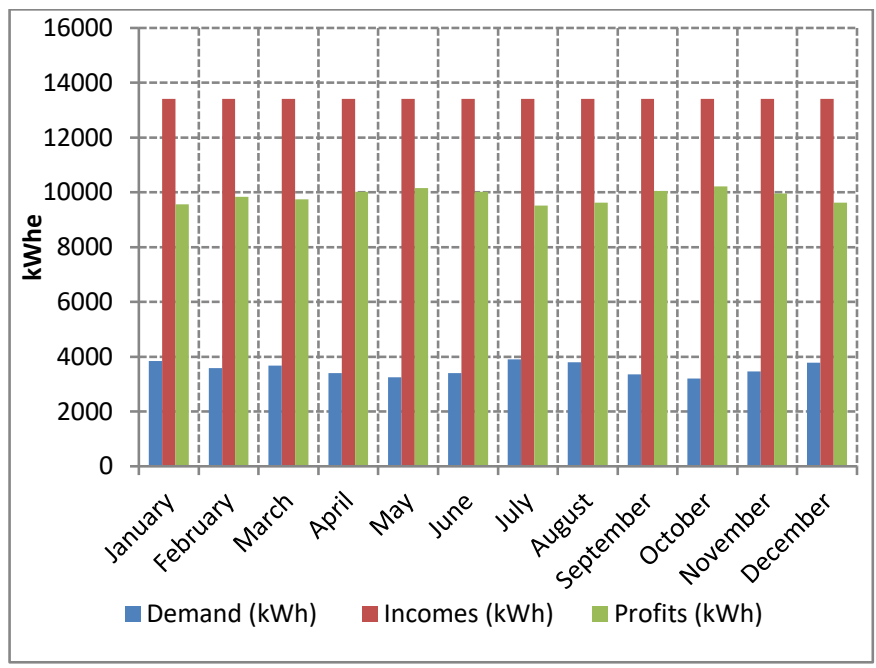

Fig. 1. Monthly profits in (kWh) from biogas.
Establishing a batch digester in "Fogi" Farm is profitable for the company because the handling and the storage of the feedstock is already available within the farm territory; have low operation costs and low costs of the mechanical technologies; this process is also a contribution to the reduction of farm waste. [6], [7].

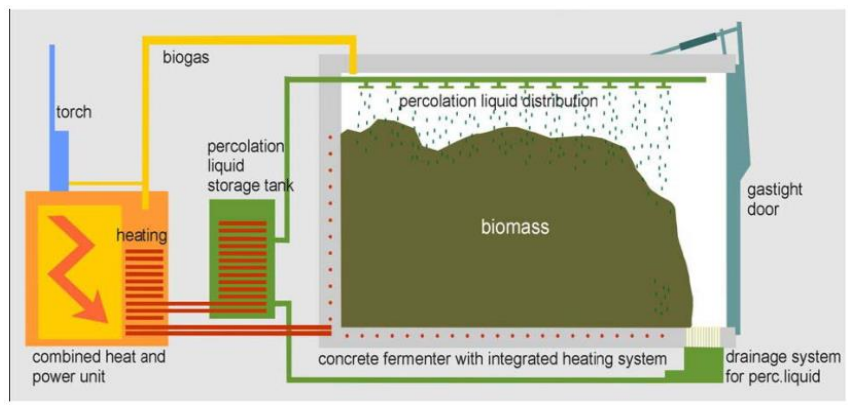

Fig. 2. Batch digester.

Total installed costs for an AD biogas plant can depend on the feedstock. Those based on manure and sewage are typically cheaper. This is because the handling and storage of the feedstock is already available [8], [9].

According to the literature review the total installed capital costs for an anaerobic digestion system vary from USD 7310 to USD $5050 / \mathrm{Nm} 3 /$ hour. This is for systems with hourly output capacities of $100 \mathrm{Nm}^{3}$ and $500 \mathrm{Nm}^{3}$, respectively [8].

Taking into consideration the biogas produced from experiments in the lab, the quantity of biogas produced is $25 \mathrm{Nm}^{3} /$ ton in a day. From 200 head cows, the quantity of biogas produced in a day is $125 \mathrm{Nm}^{3} /$ ton.

The biogas produced in an hour is $5.2 \mathrm{Nm}^{3} /$ hour. Referring to the literature [8] and to the quantity of biogas produced in an hour we calculated the initial cost of the investment that is $38072.91 \$$.

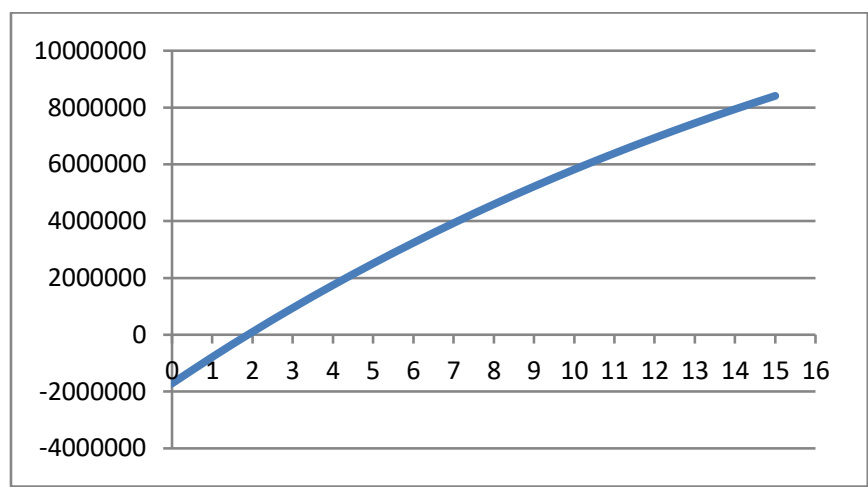

Fig. 3. The payback period of the investment cost.

The electrical capacity of the biogas plant is $161 \mathrm{MWhel} /$ year.

- Maintenance cost is 50,000 ALL (500 \$).

- Interest rate is $5 \%$.

- The cost per kWh electricity produced by biogas is 3.28 ALL $(0.0328 \$) / \mathrm{kWh}$ without VAT, a low price comparing with electricity price by national grid (14ALL, 0.14\$).

The payback period of the initial investment is 1 year and 6 months (see Fig. 3). The cash flow graphic of the investment is shown in the Fig. 4. 


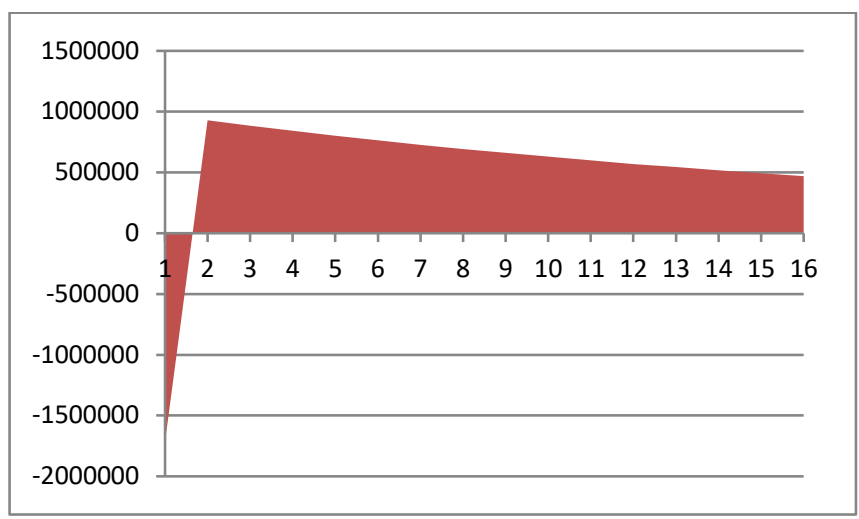

Fig. 4. Cash flow graphic of the investment.

The Net Present Value after 15 years is 14527088 ALL or 145027.8 USD.

The batch digester to be implemented in "Fogi" Farm is been studied as per real conditions.

\section{CONCLUSION}

- Different biomass samples of "Fogy farm" cow manure analyzed in the biogas lab are easily biodegradable and as result was produced a considerable quantity of biogas.

- From the case - study, the payback period is assumed 1 year and 6 months.

- Net present value 145027.8 \$.

- The cost per $\mathrm{kWh}$ electricity produced by biogas is $0.0328 \$ / \mathrm{kWh}$, a low price comparing with electricity price by national grid (14 ALL, $0.14 \$$ ) without VAT.

- The initial investment is economically profitable.

\section{REFERENCES}

[1] INSTAT Albania 2020.

[2] Decision Support System (DSS) for the application of RENEWABLE ENERGY (RE) from Biogas and Biomass Combustion under particular consideration of framework conditions in VIETNAM and THAILAND, Version 1.0, June 2005, p. 110.

[3] Martin Wittmaier -Institut für Energie und Kreislaufwirtschaft an der Hochschule Bremen $\mathrm{GmbH}$ - Fermentation of waste and organic substrates from agriculture - technical possibilities and potential for the production of generative energy. Germany 2010. 30 pages.

[4] Mirel Mico, Tania Floqi, Oltion Marko, Ana Tomorri, Rodon Miraj, Some data on biogas production in laboratory scale from different albanian substrates, 2nd International Conference - Research and Education in Natural Sciences, Proceedings book Vol. 2, BENA, Shkodër Albania 2013, pp. 107-113.

[5] Holta Prifti, Tania Floqi, European Journal of Engineering and Technology Research ISSN: 2736-576X "Biogas Production in Laboratory Scale from Different Organic Wastes Using Primary Sludge as Co-substrate", Vol 6, Issue 3, April 2021. DOI: http://dx.doi.org/10.24018/ejers.2021.6.3.2412,

[6] Technical guidance Technical Guidance on the Operation of Organic Waste Treatment Plants, Lead Authors: Marco Ricci - Jürgensen, Alberto Confalonieri, ISWA - the International Solid Waste Association, July 2016, p. 73

[7] Teodorita Al Seadi, Dominik Rutz, Heinz Prassl, Michael Köttner, Tobias Finsterwalder, Silke Volk, Rainer Janssen. Biogas handbook. Denmark 2008, p. 75.

[8] New fuels for transport: the cost of renewable solutions Road Transport: The Cost of Renewable Solutions. (C) IRENA 2013. Capital costs for biogas Cleanleap, https://cleanleap.com/6-biogas/61-capitalcosts-biogas.

[9] Environmental Engineering, Gerard Kiely, 2019.

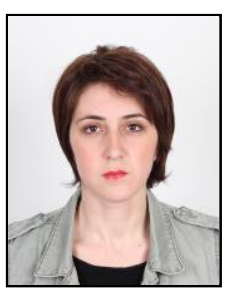

Holta Prifti, first Author in this paper, born in Albania, graduated in Environmental Engineering, Department of Environmental Engineering, Faculty of Civil Engineering, Polytechnic University of Tirana, Master degree in Environmental Science. Now in the phase of completion of $\mathrm{PhD}$ degree. She works at the National Agency of Protected Areas, Ministry of Tourism and Environment, Albania in the project sector. She follows the implementation of projects in Protected Areas in Albania; She has been lector in the Department of Environmental Engineering for three years. My mentor in PhD studies is Prof. Dr. Tania Floqi, co-Authors in this paper, Head of Environmental Department, Faculty of Civil Engineering, and Polytechnic University of Tirana, Albania. Recently, member of European University of Tirana Albania. Co-Author is also Prof. Mirel Mico, lecture, Department of Environment, Faculty of Civil Engineering, Polytechnic University of Tirana. 